\title{
THE INFLUENCE OF BLACK SEA CHARACTERISTICS OVER JOINT OPERATIONS
}

\author{
Florin NISTOR, PhD* \\ Lucian Valeriu SCIPANOV, PhD**
}

In this endeavour, it is proposed to identify some military characteristics of the Black Sea, in terms of narrow sea, that can influence the development of military action in a joint context. This will highlight the role and place of naval force in capitalizing on the optimal potential to support coastal actions carried out by the land force. The novelty of this approach is underlined by the fact that the research result is based on the cooperation of specialists from the Romanian Naval Forces with specialists from the Land Forces, following war games and the use of other research tools specific to the military science field. The originality lies precisely in the fact that the particular missions of the naval forces during the support of the land forces were identified by the authors through the experience gained in exercises carried out at the "Carol I" National Defence University. The final product will make that correspondence between the characteristics of the Black Sea and the necessary capabilities, intended to manifest maritime power, through an appropriate response in the case of joint military actions, which will contribute to supporting national interests at the maritime and riverine areas.

Keywords: narrow sea; Black Sea; military characteristics; joint operations; naval forces; land forces.

\footnotetext{
* Florin NISTOR, PhD, is Professor within the Naval Forces Department, Command and Staff Faculty, "Carol I" National Defence University, Bucharest, Romania. E-mail: ronavy.florin@yahoo.com

** Lucian Valeriu SCIPANOV, PhD, is Associate Professor within the Naval Forces Department, Command and Staff Faculty, “Carol I" National Defence University, Bucharest, Romania. E-mail: shcipio@yahoo.com
} 


\section{Introduction}

The purpose of this article is to identify those Black Sea characteristics that could influence the form and method of action, forces and means intended, methods and procedures of combat in military actions carried out in a multinational context, with planned national capabilities. In this endeavour, the contribution of naval capabilities to support the action of land forces structures (Corps, Divisions, Brigades) in the area of responsibility of the Romanian Naval Forces will be identified. Since the Romanian Naval Forces' priority is the maritime and riverine area, mainly the Black Sea and the Danube River, furthermore, this aspect is the central point of the analysis. Moreover, the aim of the paper is to identify key issues in the collaboration between land forces specialists (hereinafter the generic term land forces will be used) and Romanian Naval Forces, based on lessons learned, research results, war games, disseminated products, other relevant aspects as a result of the authors' experience, acquired in the field of maritime operational art. The starting point in this approach is our country's geographical position in relation to the most experienced opinions of specialists in the field, who have identified the most important characteristics of the enclosed seas. According to the author, this aspect forces military strategy specialists to identify those suitable response solutions, in relation to national interests in the Black Sea region. In the maritime field, it is appropriate that these decisions lead to the choice of the most effective measures and means of response. From this perspective, the expectation is to achieve that correspondence between the characteristics of the Black Sea and the necessary capabilities, intended to manifest maritime power, through an appropriate response in the case of joint military actions that contribute to supporting national interests at maritime and riverine area.

Generally, the geographical position of a riverine country, with a coastline in a narrow sea, allows or facilitates the expression of maritime power. From this stand point, a component of maritime power, such as geographical position, economic and political interests, which are usually considered advantages, may also diminish their importance if the geographical position is not one of interest, compared to the geographical context of the narrow sea. However, the advantages should not be minimized, even if one component of maritime power is not clearly exploited or highlighted, because the other components may compensate for this deficiency.

In order to see the connection between the manner of manifestation of maritime power, implicitly of naval power, with the mode of action of a fleet for the purpose of manifesting the national interest at maritime and riverine area, in this article, the following objectives have been established:

- presentation of the main characteristics of the narrow seas;

- identifying the characteristics of the Black Sea (as a narrow sea) in terms of 
modern warfare;

- identifying the contribution of naval forces to the actions of the land forces structures support in the military actions near the coastline;

- the correspondence between the mode of action, the forces and means intended, the methods and procedures for combating the characteristics of military actions carried out in narrow seas.

As seen, the objectives of this approach are directly related to the military characteristics of the narrow seas, from a perspective of the characteristics of modern warfare. The analysis is based on the authors' experience in the field, as a result of the development of research in the field of modern operative art, the results of war games for combat scenarios in maritime and riverine environments, on the surface, in the air and underwater. This experience was gained through participation and contribution to activities carried out over the years, exercises, studies, analyses, round tables, or debates in seminars or discussions between specialists.

In terms of manifestation of naval power, if we briefly analyse the most famous military actions in history, we can see that narrow seas were the place of naval action in regional conflicts (local conflict) and less in major conflicts. In fact, the famous professor Milan Vego points out that the most common possible scenarios for narrow seas are:

- "limited war or regional conflict;

- a war restricted to a specific geographic area and fought either between a major and one or more minor power, or a war between two major powers to accomplish limited strategic objectives." (by which one can understand a war restricted to a specific geographic area, a fight between a major and one or more minor powers, or a war between two major powers.)

In other words, it is acknowledged that in the future a narrow sea will be a secondary area of operations within a war theatre, where two major actors with regional interests will most often be involved.

It is also expected that smaller regional actors will form alliances, coalitions, against major regional actors. From this viewpoint, the aim is to identify those national capabilities and the mode of action depending on the characteristics of modern narrow sea warfare, which may respond to threats from the sea in the Black Sea region.

In the following, a critical analysis of the main characteristics of a narrow sea will be carried out, and, also, an analysis of the main military characteristics of the Black Sea will be performed, based on three research hypotheses, which will validate the research objectives.

\footnotetext{
${ }^{1}$ Milan N. Vego, Naval Strategy and Operations in Narow Seas, US Naval War College, Newport, Rhode Island, Ed. Routledge, 2013, p. 11.
} 


\section{The Main Features of a Narrow Sea}

From a military standpoint, the main features of a narrow sea can be highlighted according to specific criteria:

- by spatial criterion: space/action area reduction, due to the autonomy of platforms and range, but also the reduction of distances to military objectives;

- by actional criterion: increasing the action intensity, quick decision of the action outcome;

- by temporal criterion: short action times, due to the relatively short distances in relation to the operating speed of modern platforms;

- by informational criterion: real-time contribution and realization of Recognized Maritime Picture (RMP).

Given these criteria for the analysis of a narrow sea from a military point of view, it would be inferred that:

- the possibility of major confrontations is minimized, but low-intensity military action would not be ruled out: naval battles, blows, clashes;

- military actions are carried out under the auspices of peace operations, the promotion of diplomacy, etc.;

- military actions are directly influenced by the hydrography of the narrow sea, depths, salinity, currents, etc. (includes the type of platforms used).

Therefore, in the authors' opinion, these will be considered working hypotheses in the further research.

Also, following an analysis of the opinions of specialists in the field, it may be considered necessary to consider some scenarios that may take place in narrow seas. Possible scenarios for limited conflict at narrow sea include:

- "a limited war of intervention;

- a limited war between major powers evolving into entirely naval conflict;

- harassment of enemy and/or neutral shipping in international straits or narrows;

- a dispute over an economic exclusive zone EEZ;

- local conflict in a typical narrow sea fought between two or more minor powers while major powers remain strictly neutral," ${ }^{2}$ even though a major power may provide support to one or more of its partner interests.

In the aftermath, some preliminary conclusions can be drawn, which complements the corollary of the narrow sea characteristics:

- electronic and cyber warfare is facilitated;

- the use of mainly short and medium-range missiles is expected;

- actually, small naval groups deployment is expected to be assigned;

- limited objectives are targeted, and here we refer to certain characteristics of

${ }^{2}$ Milan N. Vego, op.cit., p. 11. 
an objective, such as:

- spatial-geographical objectives (maritime areas, ports, communication lines, islands, straits),

- destination of the objective (mainly economic, military), etc.,

- the importance of the objective (tactical, operational, or strategic level, etc.).

In view of the conclusions reached above, a brief analysis of the military characteristics of the Black Sea will be carried out.

\section{The Main Military Characteristics of the Black Sea}

Given the main narrow sea characteristics, supported by analysis criteria related rather to the military level that it will be considered working hypotheses, with the partial conclusions presented, an analysis of the main military characteristics of the Black Sea will be performed, The Black Sea is considered a narrow sea because the access between it and the Planetary Ocean is made through the Bosphorus and Dardanelles straits, but we must not neglect access through the Pan-European CorridorVII, Rihn-Main-Danube, or the Russian canals, with the limitations imposed by the minimum drafting.

Therefore, it will be developed the analysis according to the levels of military art: strategic, operational as well as tactical level.

\subsection{Strategic level}

The main issues that need to be taken into account by military decision-makers and that produce effects at the strategic level are presented below.

Firstly, combat actions can be carried out with intensity (high intensity ${ }^{3}$ ), simultaneously on the entire surface of the Black Sea. Sometimes, due to the autonomy of modern ships, the theatre of military actions can be extended to adjacent seas, such as the Mediterranean, Azov, or the Baltic Sea, including by involving coastal capabilities. The Black Sea was the scene of naval actions in regional conflicts (local conflict ${ }^{4}$ ) or in major conflicts, as a secondary theatre of operations.

Secondly, the air strikes are much more decisive than similar military actions carried out in history. Also, airpower can be much more decisive than naval power, consequently, airpower can be decisive in the war at sea. Decisive military actions will be characterized by the predominant use of high-precision weapons $/ \mathrm{missiles}^{5}$, the foundation of the A2AD concept. Hence, from this perspective, it must be taken into consideration that the naval Task Groups (TGs) are very vulnerable to missiles strikes, and for this reason, aerial protection is needed.

${ }^{3}$ Ibidem, p. 12.

${ }^{4}$ Ibidem, p. 11.

${ }^{5}$ Ibidem, p. 12. 
On the other hand, the naval action has an operative-tactical role, but the decisive role that a naval battle may play in the evolution of the frontline is not excluded. Here, one example can be given: regaining control of the sea, while maintaining air superiority. At the strategic level, one of the main objectives of a participant in military action is the reopening of maritime communications and their protection. Here, modern Turkey, in a position of the successor of the Byzantine Empire, and later on of the Muslim Turkey, held undisputed control of the Straits ${ }^{6}$. Therefore, they have dominated trade in the Black Sea region, and are able to control the incursion into the Black Sea area. In this case, the Montreux Convention becomes a strategic negotiating tool, with all its implications.

Finally, the main military actions will take place near the coast, on land, and at the seaside. "One of the principal task of naval strategy in peacetime is to build or acquire a sufficient number of naval and bases to allow one's forces to accomplish national and military strategic objectives in wartime" of well-defended naval bases, connected to the communications network, with supply possibilities, is a strategic objective.

Therefore, in a preliminary conclusion, the Black Sea will remain a secondary area of operations. Hence the role of the navy for specific missions, less decisive at the strategic level, but important at the operational and tactical level.

\subsection{Operational level}

In the light of the foregoing, it can be stated that the geometry of the battlefield in narrow seas is different from the rest of the seas. If the main elements of the theatre of maritime operations are: "base of operations, physical objectives, decisive points, lines of operations, lines of communications", in the case of the narrow sea" these elements are spaced rather densely because of the much shorter distances involved", then, the role of the military planner is to identify the maximum effects that the actions of the naval forces can produce on the components of the maritime operation theatre, in relation to the actions of the other components of the joint level.

From a special point of view (physical objectives), if we refer to the maritime theatre component, a country may be situated in such a way as to control the whole or part of the sea, or is in a position at a certain distance from the straits or it holds the straits. In peacetime, the maritime space is controlled by diplomatic means, including by building alliances or coalitions between riparians or appropriate actors. During wartime, the straits are much more important. Maritime space control is, in this case, an operational level objective.

\footnotetext{
${ }^{6}$ Ibidem, p. 17.

${ }^{7}$ Ibidem, p. 61.

${ }^{8}$ Ibidem, p. 75.

${ }^{9}$ Idem.
} 
In general terms, the concepts Sea Control and Sea Denial represent mainly the control of maritime communications (lines of communications). In narrow seas, because of the short distances, a blue water fleet contributes to obtaining the control of the sea, (including control of the air and land space adjacent to the coast) except for the submarine space, if a potential enemy owns a fleet of submarines. In this case, a fleet specially designed for anti-submarine combat, including underwater combat capabilities (submarines, UUVs, mines, underwater surveillance systems, etc.), is required. Therefore, conceptually, we consider the term Sea Control rather than the Command of the Sea more appropriate in the case of narrow sea.

Starting from the statement "The smallest navy can make sea control complicated for a major navy"10. From this point of view, it is very easy to have control of the sea in the high seas and very difficult, almost impossible in the narrow seas. And this is not due to the presence of a fleet of blue water, but to the presence of coastal defence systems, coastal missiles, and the system of mine dams, including engineering or the coast against landing arrangements.

In the case of decisive points, identified as a result of the application of the operative art during the planning of the operation, the theory describes that there are several operational phases between the phases of the conflict. In the authors' opinion, in narrow seas, these operational pauses can be unnecessary. This is because of the rhythm of the operation, which compacts the time of action. "The high intensity of naval action will result in a rapid change in a situation. Sudden shift from offense to defence or vice-versa" ${ }^{11}$ Therefore, decisive points must be identified in the light of these changes in the situation. Thus, during the joint operation, the operational situation may undergo radical and frequent changes ${ }^{12}$, this being as a consequence of the characteristic of the modern naval war, carried out by the air-naval component. But not to minimize the actions with characteristics of hybrid warfare, "hybrid warfare can be the sum of all actions regardless of their nature" ${ }^{13}$, which leads us to consider that at sea it acquires particular characteristics. But, it is mandatory to emphasize that the manoeuvrability of the air forces at sea is an advantage. Therefore, the decisive points must be identified according to these changes in the situation or advantages.

Also, an instrument that offers strategic-operational advantages is electronic warfare, more recently cyber warfare. The use of electronic warfare can make difficult or impossible the use of sensors and guided weapons ${ }^{14}$. Furthermore, the

\footnotetext{
${ }^{10}$ Milan N. Vego, op.cit., p. 111.

${ }^{11}$ Ibidem, p. 12.

${ }^{12}$ Idem.

${ }^{13}$ Daniel Roman, Cristian-Octavian Stanciu, „The operational art in the context of range of threats specific to the contemporaty Security environment", GlobState III, Web Conference, 16-20 November 2020, Polish Armed Forces Doctrine \& Training Centre Kazimierz Wielki University, p. 123.

${ }^{14}$ Milan N. Vego, op.cit., p. 12.
} 
use of unmanned vehicles (UV)may be disturbed. But, it is compulsory to underline that the air force manoeuvrability is an advantage.

From all the characteristic aspects at the operational level, a conclusion can be drawn very precisely, namely, the two-way relationship between the actions of the naval and coastal forces and the actions of the coastal land forces, which in turn depend on the outcome of the air forces in the battle to maintain a minimum level of control of airspace, which is, in the authors' opinion, one of the most important conclusions of this paper approach.

\subsection{Tactical level}

Tactically, it can be stated that the high speed of modern ship and the ability to combine manoeuvre and firepower become an advantage that gives superiority, as well as surprise in the battlefield. Military actions take place mainly at night, especially at dusk (sunrise and sunset).

In the narrow seas, the deployment of coastal combat forces and maneuvering tactical forces can be more difficult.

On the surface, after each air attack, it is difficult to rejoin forces. The time available between two successive attacks is not enough to reorganize the combat disposal, nor to complete it.

In terms of tactical objectives, the ground-based air force is the most effective way to strike at marching naval Task Groups (TGs) or based in ports, including port facilities.

A partial conclusion can already be drawn, namely, the naval confrontation in narrow seas can be achieved by deploying a heterogeneous naval TG. Also, the mission, objectives, and duration of the action are defined by limited goals, well established in time and space.

Given the military characteristics of the Black Sea, the authors recall some actions that support the partial conclusions presented: the action of the naval group Datoria on Georgian ships, the hybrid action in Crimea, the actions around the Kerch Strait, seizures of ships and naval actions on the Donetz coast, these being some of the most recent actions. If we analyse these actions, we will find that many of the military characteristics of the Black Sea have been taken into account by military planners, the success of the actions being a tangible proof.

\section{Aspects of Land Forces Support in Coastal Military Actions}

\subsection{For the land forces support in the littoral actions}

First of all, the land forces must take into account the fact that the Informational Preparation of the Battlefield (IPB) must be carried out on the entire surface of the Black Sea, the future actions being dependent on the information interest area. 
Secondly, the naval forces' action to carry out the RMP is a support action of the land forces. The minefield is a No Go area in IPB of land forces.

Furthermore, in case of an amphibious operation, the naval component may permanently inform the land forces on all phases of the operation.

Also, the actions of the naval forces can cause the opponent to change the COA. For that, it can be mentioned the minelayer, artillery strikes, the use of naval strike missiles (NSM) from the coast, etc.

Regarding the fight against amphibious forces, the naval forces can contribute to rejecting, delaying, channelling, destroying enemy landing forces. Counterlanding is a specific coastal action that the naval forces can carry out both at sea and at the river's mouth.

In classic actions, the naval forces' capabilities represent a support capability on the flank of the land forces. Therefore, the Navy action always depends on coastal Army action.

All in all, the naval forces contribute to and are able to carry outland forces support in the littoral and coastal actions by:

- systematic actions (presence, deterrence, supervision)

- information support

- realization and updating of the RMP

- modelling the tactical field

- limiting enemy actions

- delaying, channelling

- causing losses

- require the enemy to choose another, more unfavourable COA, etc.

\subsection{For the land forces support in the fluvial and riverine actions}

Similar to the previous paragraph, on the riverine area, IPB is common to land forces and the naval forces components.

In defensive, the riverine zone is mainly the Slow Go zone. Minelaying of obligatory river crossing points, becomes the NO GO on river communications.

In the offensive, the land forces formed in the riverine landing forces, supported on the flank by the riverine or fluvial naval forces, serve as return detachment. Simultaneous counterattacks from several directions with tactical subunits represent a characteristic of a riverine operation.

In terms of command and control (C2), decentralized command and control of the forces represent another characteristic of the riverine operation.

Also, the action of the riverine forces represents the action to support the land forces on the coast and on the river communications:

- supporting the land forces in the bridgehead;

- ensuring dredging and marking of the corridors through the mine dams; 
- mine laying and isolation of riverine areas;

- ensuring the transport of troops from the embarkation area to the disembarkation area;

- combat landing of the riverine forces;

- fire support of the riverine forces during landing and subsequent actions;

- ensuring the supply of the disembarked riverine forces;

- ensuring the withdrawal of the rejected landing forces in the bridgehead.

\section{Conclusions}

Based on the presented arguments, we are able to underpin the role and place of the Romanian Naval Forces, as the most visible national instrument of manifestation of naval power. The size of the task forces (TFs) or task groups(TGs) for narrow seas is not so large compared to a TFs for an open seas confrontation with much wider spaces. This justifies the focus on the actions of the naval forces bordering the Black Sea (Azov, Marmara, and the Mediterranean).

The naval confrontation in the Black Sea can be achieved by deploying a heterogeneous task group (TG heterogeneous). The defence against enemy maritime/riverine landing forces is solved by a joint effort, within the collective defence. Hence, the fact that operations in the narrow seas are clearly different from those carried out in the high seas. Thus, the structure of a naval group (TF/TG) in the narrow sea is different from a naval group operating in the high seas.

The decisive operation can aim at the destruction of the enemy landing force, the main effort being the Land Force! The narrow sea becomes integrated battlefieldt the combat actions will take place simultaneously in the terrestrial, air, and maritime environment. For this reason, we cannot minimize the role of the components of the Army, (Land, Air, and Navy Forces). Under these circumstances, we consider that the dependence between the categories of forces acting at the seashore is much more accentuated, the air forces having an undeniable importance.

However, the most important aspect of the research highlights the dependence between the actions of the land, naval and air forces in military actions in the Black Sea region, considered a narrow sea. As authors, we emphasize as an aspect of novelty and originality, that the missions of the naval forces in support of the land force structures have been identified through personal experience and in many military exercises carried out within "Carol I" National Defence University.

\section{BIBLIOGRAPHY:}

1. ***, Collective of authors, Tactical command exercise in education command post MUNTENIA 2019, 2020, "Carol I" National Defence University, Bucharest, 
Romania, Military biblioghaphy, DA 418/NS; DA 326/NS.

2. ***, Exercise scenario by simulation "MAGISTERIUM", 21.07. "Carol I" National Defence University, Bucharest, Romania, Aplications biblioghaphy: APL 235/2021.

3. ROMAN, Daniel; STANCIU, Cristian-Octavian, "The operational art in the context of range of threats specific to the contemporaty security environment", GlobState III, Web Conference 16-20 November 2020, Polish Armed Forces Doctrine \& Training Centre Kazimierz Wielki University.

4. SCIPANOV, Lucian Valeriu; MAXIM, Valentin, "Considerations regarding on the russian doctrine for a new warfare model in the Black Sea region", Strategic Impact Journal, "Carol I" National Defence University Publishing House, Issue 78, vol 1, 2021.

5. SCIPANOV, Lucian Valeriu; NISTOR Florin, Considerations on the military actions conducted in the North of Black Sea, Bulletin of "Carol I" National Defence University, Bucharest, Romania, 2015, Vol. 2, No. 2.

6. VEGO, Milan N., Naval Strategy and Operations in Narow Seas, US Naval War College, Newport, Rhode Island, Routledge, 2013. 